DOI 10.32755/sjcriminal.2020.02.094

Pekarchuk V. M., Doctor of Sciences (History), Professor, Head of Law Faculty, Academy of the State Penitentiary Service, Chernihiv, Ukraine ORCID: 0000-0002-7750-1474;

Havrysh N. R.,

Officer of the 361-st academic group, Academy of the State Penitentiary Service, Chernihiv, Ukraine

\title{
PROBLEMS OF NORMATIV-LEGAL REGULATION OF CITIZENSHIP IN UKRAINE
}

The article reveals the concept of the category "legal regulation" and defines the essence of legal regulation of the institution of citizenship in Ukraine. It was found that the system of constitutional and legal norms governing citizenship is formed by the institution of citizenship, the sources of which are: the Constitution of Ukraine; current international agreements of Ukraine on citizenship issues, the binding nature of which has been approved by the Verkhovna Rada of Ukraine; laws of Ukraine; bylaws governing legal relations in this area.

The essence of Ukrainian citizenship is studied, as well as the grounds for acquiring Ukrainian citizenship are determined. Problems concerning the legal regulation of the institution of citizenship are analyzed, in particular, in the part of dual citizenship, which need an immediate solution at the legislative level. At present, dual citizenship needs a balanced policy based on the objective trend of spreading this phenomenon in the context of globalization processes in Ukraine.

Key words: legal regulation, normative-legal regulation of the institution of citizenship in Ukraine, citizenship of Ukraine, dual citizenship, national legislation.

Target setting. The citizenship issue has been relevant throughout the states's development. The Universal Declaration of Human Rights stipulates that the right to citizenship is one of the fundamental rights by which a person can acquire the citizen status of a certain state, and thus acquire a set of rights and responsibilities. Due to the citizenship acquisition, any citizen becomes a full member of society. In addition, the citizenship acquisition by a person is the basis for the emergence of a legal relationship between the state and the citizen. At present, the issue of an effective system of regulation and ensuring of the right to citizenship and its mechanism remains relevant, which, in turn, is the key to the existence of a modern state, as the usual declaration of any concept even at the highest legislative level does not mean its effectiveness. 
Analyses of the latest research and publications. The issue of legal regulation of citizenship has been studied by a number of wellknown domestic scientists. Among the works on this topic we can note the works of such authors as Bedriy R.B., Vitruk N.V., Voievodin L.D., Zhuravka O.V., Zemtsova B.C., Zlatopolskyi D.L., Kolodiyi A.M., Lazarev V.V., Lotiuk O.S., Melashchenko V.F., Oliynyk A.Yu., Pohorilko V.F. and others. Given the complex nature of the problem of the institution of citizenship in Ukraine, many aspects are still unresolved, in particular with regard to the legal regulation of citizenship, so this issue requires further research and some changes at the legislative level.

Purpose setting. The purpose pf the study is the essence of legal regulation of citizenship, as well as proposals to improve legislation in the field of citizenship.

The main material. The citizenship combines meaning and form, like any other state and legal phenomenon. At the same time, the legal nature of this phenomenon is revealed through the state's legal regulation of the institution of citizenship. The characteristic feature of such legal regulation should be considered the presence of a specific mechanism, the structural elements of which include the rules of law, objectified in the relevant regulations. Before revealing the essence of the legal regulation of Ukrainian citizenship, at first we have to define such a concept as "legal regulation". It is important to analyze different approaches to defining this concept in legal science and literature. Since today among scholars there is no unity of positions regarding the definition of the essence and concept of legal regulation.

The New Explanatory Dictionary of the Ukrainian Language does not define the concept of legal regulation, but defines the essence of the concept of regulation as such. According to such provisions the term "regulation" means the ordering of something, control of something, subjecting it to the relevant rules, a certain system in order to achieve normal operation or coordinated interaction of components and/or to achieve the appropriate degree of detection [1, p. 1207].

Since the law regulates public relations, so according to this, the definition of "legal regulation" can be formed as an order through the law of public relations. 
In order to define the concept of "legal regulation", we should refer to the legal encyclopedia, which gives the following definition: "Legal regulation (in Latin "to regulare" - to direct, organize) - one of the main means of state influence on public relations in order to regulate them in the interests of man, society and the state" [2, p. 40]. However, the definition of legal regulation, in addition to defining it as a phenomenon, must also define its main task. Therefore, it should be noted that the above mentioned definition is quite narrow since it defines the purpose in a way the state seeks to achieve through such regulation.

According to Rabinovych P.M. opinion, legal regulation - is state power influence on public relations in order to its streamline, consolidation, protection and developing carried out by the entire system of legal means [3, p. 137]. Teremetskyi V.I. notes that legal regulation is a specific activity that is a means of regulating public relations through the norms of law. The scientist emphasizes the essence and the main task of regulation is to streamline and establish a mechanism of interaction between the subjects of social relations [4, p. 51]. Under the term of legal regulation Skakun O.F. understands the regulating public relations, their legal consolidation, protection and development carried out by the state with the help of law and a set of legal means [5, p. 488].

Legal regulation is carried out through special legal means, which include legal phenomena expressed in guidelines, actions and technologies that meet the interests and needs of legal entities and achieve socially useful purposes. This thesis can be considered in such approaches of scientists to determine the essence of legal regulation, namely: to be considered as the influence exerted by the whole system of legal remedies on public relations in order to streamline them (Malko A.V.) [6, p. 5]; the influence of law on public relations through legal means: the norms of law, legal relations, acts of law (Bobiliov A.I.) [7, p. 10]; purposeful influence on social relations, carried out by legal means (Shundikov K.V.) [8, p. 54].

From these definitions analysis it is clear that each authors' definition is different on a clear list of instruments that are included in the measures of legal influence. These measures should include those tools by which public relations form the subject of legal 
regulation, acquire a legal form, and, consequently, happening the regulation of the subjects of the relevant legal relations. The legal regulation, first of all, regulates public relations with the help of normative-legal regulations designed for their repeated application in the presence of the circumstances provided by them, that is an objective law (system of legislation) [9, p. 189].

By clarifying the essence of legal regulation in the future, we consider to disclose the normative-legal regulation of citizenship.

It is worth saying scientists do not have a single approach to this issue. Thus, Pohorilko V.F. and Fedorenko V.L. distinguish the following types of sources of the legal institution of citizenship: 1) the Constitution of Ukraine; 2) Law of Ukraine "On Citizenship of Ukraine"; 3) other normative-legal acts of Ukraine, which are issued in accordance with the Constitution and the Law of Ukraine "On Citizenship of Ukraine" [10, p. 114]. Whereas, Kravchenko V.V. identifies the following sources of the institution of citizenship: 1) the Constitution of Ukraine; 2) Law of Ukraine "On Citizenship of Ukraine"; 3) current international agreements of Ukraine on citizenship issues; 4) bylaws acts [11, p. 118]. A similar opinion is held by Frytskyi O.F. [12, p. 132-133], Rubach L., Milorava M., Kotsiuba V. [13, p. 5].

Despite the above mentioned views, Article 4 of the Law of Ukraine "On Citizenship of Ukraine" establishes three types of sources governing citizenship: the Constitution of Ukraine, the Law of Ukraine "On Citizenship of Ukraine", international treaties [14, p. 106].

Thus, it can be concluded that the normative-legal regulation of the institution of citizenship by means of normative-legal acts regulates public relations in the sphere of acquisition and termination of citizenship, as well as in resolving other issues related to citizenship. These normative-legal acts, properly regulated, form a certain system, which do not exist in isolation, but are in close cooperation with other normative-legal acts, which regulate related legal relations.

It should be noted that the system of constitutional and legal norms governing the issue of citizenship forms the institution of citizenship, the sources of which are: the Constitution of Ukraine; current international agreements of Ukraine on citizenship, the binding nature of which has 
been approved by the Verkhovna Rada of Ukraine; laws of Ukraine; bylaws acts governing legal relations in this area.

The provisions of the above mentioned normative legal acts enshrine the principles of citizenship and regulate the procedure for acquiring and terminating citizenship, as well as determine the powers of public authorities and other organizations and institutions involved in resolving issues considering citizenship.

Article 4 of the Constitution of Ukraine defines one of the basic principles of citizenship: "There is a single citizenship in Ukraine. The grounds for acquiring and terminating the citizenship of Ukraine are determined by law" [15]. This provision of the Constitution is aimed at achieving a single legal status for every citizen in relations with Ukraine.

According to Article 1 of the Law of Ukraine "On Citizenship of Ukraine", citizenship of Ukraine is a legal relationship between an individual and Ukraine, which is reflected in their mutual rights and responsibilities. A citizen of Ukraine - is a person who has acquired the citizenship of Ukraine in the manner prescribed by the laws of Ukraine and international treaties of Ukraine [16]. The understanding of a man as a citizen is of great importance, also as the definition of his social, political and legal essence, because with the acquisition of citizenship to some extent a person joins the life of the state.

Article 6 of the above mentioned Law of Ukraine clearly defines the grounds for acquiring Ukrainian citizenship, namely: 1) by birth; 2) by territorial origin; 3) as a result of admission to citizenship; 4) as a result of renewal of citizenship; 5) as a result of adoption; 6) as a result of establishing custody or guardianship over the child, placement of the child in a children's institution or health care institution, in a family-type orphanage or a foster family or transfer for upbringing to a foster family; 7) as a result of establishing guardianship over a person declared incapable by a court; 8) in connection with the stay in the citizenship of Ukraine of one or both parents of the child; 9) as a result of recognition of paternity or maternity or establishment of the fact of paternity or maternity; 10) on other grounds provided by international agreements of Ukraine.

As a result of resolving citizenship issues, contrary to various regulations and codified legislation, conflicts arise when the same 
person is a citizen of several countries at once. In constitutional science, this phenomenon is called dual citizenship.

It should be noted that the legislation of Ukraine does not contain a direct prohibition on dual citizenship or the possibility of having a second citizenship. Moreover, the legislator has not defined any sanctions for multiple citizenship. According to Part 1 of Article 19 of the Law of Ukraine "On Citizenship of Ukraine", voluntary acquisition by a citizen of Ukraine a citizenship of another state is grounds for termination of citizenship of Ukraine: 1) voluntary acquisition of citizenship of another state by a citizen of Ukraine. Voluntary acquisition of citizenship of another state is considered to be all cases when a citizen of Ukraine in order to acquire citizenship of another state must apply for such acquisition in accordance with the procedure established by the national legislation of the state of which he acquired citizenship [16]. However, even this circumstance cannot be regarded as a prohibition of dual citizenship, as the loss of Ukrainian citizenship does not occur automatically with the acquisition of citizenship of another state, but only from the date of the Decree of the President of Ukraine on termination of citizenship.

In addition, it has not been established exactly how citizens of Ukraine should declare their second citizenship. After all, in our state there are no forms of fixing dual citizenship. It is currently almost impossible to prove the existence of dual citizenship, and many countries, such as Israel, Romania, and Hungary, do not issue certificates of dual citizenship, which makes the enacted law impossible.

The negative aspect of dual citizenship can be a change of national identity or the promotion of dual national identity, because one of the main conditions is to prove belonging to, for example, Hungarian or Romanian nationality. Ukraine is also threatened by the problem when at least one-fifth of the region's population receives foreign passports, it may be the reason for claims to autonomy. For example, some political forces of Romania have long harbored the idea of the revival of Greater Romania, including Bukovina and Bessarabia, and therefore so actively distribute Romanian passports to their neighbors $[17, \mathrm{p} .47]$. 
The recent situation with the spread of hidden dual citizenship indicates the socio-political situation in some regions of Ukraine tends to increase destabilization with the transition to threats to the territorial integrity of Ukraine. Existing ethnic confrontations and attempts by other countries to exploit diaspora issues in their own interests can lead to ethno-national and interstate conflicts. Among the foreign policy factors that negatively affect the process of national consolidation of Ukraine, we can mention the spread of hidden dual citizenship, as it contributes to the formation of dual national identity, strenghthens interethnic contradictions in some regions of Ukraine, exacerbates interstate relations.

Conclusions. Thus, the normative-legal regulation of the institution of citizenship is a set of normative-legal acts that regulate public relations in the field of acquisition and termination of citizenship, as well as in resolving other issues related to citizenship. Legal regulation of the institution of citizenship is regulated by the Constitution of Ukraine; current international agreements of Ukraine on citizenship, the consent to the binding nature of which was given by the Verkhovna Rada of Ukraine; laws of Ukraine; bylaws governing legal relations in this issue.

Currently, there is an acute problem regarding the legal regulation of the institution of citizenship in Ukraine, in particular, in the issue of dual citizenship, which needs to be addressed immediately at the legislative level. Until now, the legislation of Ukraine does not prohibit dual citizenship or the possibility of having a second citizenship. Moreover, the legislator has not defined any sanctions for multiple citizenship. It is not established how exactly the citizens of Ukraine should declare their second citizenship. After all, in our state there are no forms of fixing dual citizenship. It is currently almost impossible to prove the existence of dual citizenship.

Therefore, dual citizenship needs a balanced policy, which would be based on the objective trend of this phenomenon spread in the context of globalization in Ukraine. In our opinion, it is expedient to enshrine in the Law of Ukraine "On Citizenship of Ukraine" the provisions on the obligation of a Ukrainian citizen to report the facts of dual citizenship and the introduction of criminal liability for 
violation of this obligation, as well as restrictions on dual citizenship to hold public authorities of any level.

\section{References}

1. Busel, V. T. (2005), Large Explanatory Dictionary of the Modern Ukrainian Languag, Perun, Kyiv-Irpin.

2. Shemshuchenko, Yu. S. (2003), Legal Encyclopedia, Vol. 5, Ukr. Encyclopedy, Kyiv.

3. Rabinovich, P. M. (2007), Fundamentals of the General Theory of Law and the State, Krai, Lviv.

4. Teremetskyi, V. I. (2012), "The concept of administrative and legal regulation in the field of taxation", State and Region, Series "Law", № 1 (35), pp. 50-54.

5. Skakun, O. F. (2010), Theory of State and Law, Legal unity, Kyiv.

6. Malko, A. V. (2004), Incentives and Restrictions in Law, Yuryst, Moscow.

7. Bobylev, A.I. (2002), "Theoretical problems of legal regulation", Law and Policy, № 8, pp. 10-16.

8. Shundikov, K. V. (2001), Legal regulation mechanism, Saratov, pp. 54.

9. Surzhynskyi, M. I. (2007), "Constitutional and legal regulation of the community of Ukraine", State and Law, № 3 (37), pp. 189-195.

10. Pohorilko, V. F. and Fedorenko, V. L. (2006), Constitutional Law of Ukraine, Pretsedent, Kyiv.

11. Kravchenko, V. V. (2007), Constitutional Law of Ukraine, Atika, Kyiv.

12. Fritskyi, O. F. (2003), Constitutional Law of Ukraine, Yurinkom Inter, Kyiv.

13. Rubach, L., Milorava, M., Kotsiuba, V. (2009), Citizenship: acquisition and termination, Kyiv.

14. Legislation and normativ-legal acts, which regulate migration processes, registration of individuals, citizenship issues, registration of documents (2007), Vol. 1, Kyiv.

15. Constitution of Ukraine (1996), "Constitution of Ukraine", Constitution dated June 28, 1996, №254к/96-BP, Verkhovna Rada of Ukraine, Official Bulletin of Ukraine dated October 01, 2010, № 72/1. Art. 2598.

16. Ukraine (2001), "On citizenship of Ukraine": Law of Ukraine dated January 18, 2001, № 2235-III, Official Bulletin of Ukraine dated March 16, 2001, № 9, Art. 342.

17. Lutsishyn, H. I. and Matkovskyi, I. Y. (2018), "Challenges and threats of hidden dual citizenship in modern Ukraine", Scientific journal "Politikus", Vol. 2, pp. 44-49. 


\section{Пекарчук В. М.,}

доктор історичних наук, професор, начальник юридичного факультету, Академія Державної пенітенціарної служби, м. Чернігів, Україна ORCID: 0000-0002-7750-1474;

Гавриш Н. Р., слухач 361-ої навчальної групи, Академія Державної пенітенціарної служби, м. Чернігів, Україна

\section{ПРОБЛЕМИ НОРМАТИВНО-ПРАВОВОГО РЕГУЛЮВАННЯ ГРОМАДЯНСТВА В УКРАЇНІ}

У статті розкрито поняття категорії «правове регулювання» та визначено сутність нормативно-правового регулювання інституту громадянства в Україні. В межах проведеного дослідження проаналізовані різні підходи до визначення поняття «правовое регулювання» в юридичній науиі та літератуpi. Встановлено, що на сьогодні серед науковиів відсутня єдність позицій стосовно визначення сутності й поняття правового регулювання. Правовое регулювання $\epsilon$ спещифічною діяльністю, яка $\epsilon$ засобом упорядкування та регламентаиії суспільних відносин за допомогою норм права. Зазначено, що правове регулювання здійснюється за допомогою спеціальних юридичних засобів, до яких зараховуються правові явища, що виражаються в настановах, діяннях і технологіях, за допомогою яких задовольняються інтереси й потреби суб 'єктів правовідносин і відбувається досягнення соиіально корисних иілей.

3'ясовано, що систему конституиійно-правових норм, що регулюють питання громадянства, утворює інститут громадянства, джерелами якого є: Конституиія України; чинні міжнародні договори України з питань громадянства, згода на обов'язковість яких надана Верховною Радою Украӥни; закони України; підзаконні акти, щцо регулюють правовідносини у цій сфері.

Дійили проміжного висновку, що нормативно-правове регулювання інституту громадянства за допомогою нормативно-правових актів упорядковує суспільні відносини у сфері набуття та припинення громадянства, а також під час вирішення інших питань, пов'язаних із громадянством. Ці нормативноправові акти, належним чином упорядковані, утворюють певну систему, вони не існують ізольовано, а перебувають у тісній взаємодї з іншими нормативноправовими актами, якими унормовано суміжні правовідносини.

Досліджено сутність громадянства України, а також визначено підстави для набуття громадянства України. Проаналізовано проблеми щодо правового регулювання інституту громадянства, зокрема, в частині подвійного громадянства, які потребують невідкладного вирішення на законодавчому рівні. На сьогодні подвійне громадянство потребує виваженої політики, яка базувалася б на об 'єктивній тенденції поширення ивого явищза в умовах глобалізаиійних процесів в Україні.

Ключові слова: правове регулювання, нормативно-правове регулювання інституту громадянства в Україні, громадянство України, подвійне громадянство, наиіональне законодавство. 